Castañeda, C., Mendez, S., Herrero, J., Betrán, J. 2010. Investigating soils for agrienvironmental protection in arid Spain. Pp 561-568, In P. Zdruli, M. Pagliai, S. Kapur, A. Faz (Eds.) Land Degradation and Desertification: Assessment, Mitigation and Remediation. Springer-Verlag. ISBN: 978-90-481-8656-3. DOI 10.1007/978-90-4818657-0_41.

\title{
INVESTIGATING SOILS FOR AGRI-ENVIRONMENTAL PROTECTION IN AN ARID REGION OF SPAIN
}

\author{
C. CASTAÑEDA*, S. MENDEZ**, J. HERRERO*, J. BETRÁN*** \\ * Estación Experimental de Aula Dei, CSIC, PO Box 13034, 50059 Zaragoza, Spain \\ ** Réserve Naturelle Nationale Vallée d'Eyne, Ferme Cal Martinet, 66800 Eyne, France \\ *** Laboratorio Agroalimentario, DGA, Avda. Montañana 1005, 50059 Zaragoza, Spain
}

\begin{abstract}
The saline wetlands of the Monegros Desert, in the central Ebro Basin (NE Spain), host valuable biodiversity and pedodiversity. A part of this area has been proposed for inclusion in the European Union Natura 2000 network. However, agricultural intensification is changing the area as more land is consolidated for new irrigation or is plowed to earn CAP (Common Agricultural Policy) subsidies. Soil mapping is needed to assist in the delimitation of natural habitats and to make conservation compatible with agriculture. The methodology presented here to characterize agrienvironmental areas takes into account current agricultural and environmental practices. We examined the opinions of farmers and agricultural and environmental officers concerning a new agri-environmental measure which could be proposed for inclusion in the Rural Development section of the CAP. The measure would save agriculture inputs in unproductive areas and also comply with nature conservation objectives. A GIS database was built for selecting the farming plots suitable for new agricultural practices favoring biodiversity and pedodiversity. At the local scale, we used remote sensing and pedodiversity criteria for selecting low production areas to be prospected. The opinion poll resulted in a positive response and confirmed the interest of farmers in having detailed maps of those soil features that limit crop production. The soil survey reveals soil salinity, and high contents of gypsum and calcium carbonate, as significant features to map low production areas for making agriculture compatible with habitat conservation.
\end{abstract}

Key words: Monegros, Salinity, Pedodiversity.

\section{Introduction}

The Monegros saline wetlands, known locally as "saladas", are part of a unique landscape where scattered gentle depressions are surrounded by dry-farmed or recently irrigated areas. The arid climate plus the gypsiferous and calcareous rocks are determinant of the genesis and evolution of saladas. More than a hundred depressions containing ephemeral brines and halophylous vegetation have been inventoried. These wetlands are of scientific and environmental value as natural habitats for endemic microbes (Casamayor et al., 2005), plants (Braun Blanquet and Bolòs, 1958; Pedrocchi, 1998; Domínguez et al., 2006) and animals (Melic and Blasco, 1999; Baltanás, 2001). Half of the agricultural area 
has been proposed for inclusion in the European Union's Natura 2000 network. The other half will be irrigated.

The soils are shallow, calcareous or gypseous, with a low organic matter content; whitish spots occur in relatively higher topographic positions. The soils are deeper and saline in the wetlands and have a dark upper horizon; their salinity largely exceeds thresholds for crop production. Despite the low returns imposed by natural limits, dry farming often is practiced in areas of shallow soils with low water-holding capacity, even though evapotranspiration much greater than precipitation results in no yield. Due to scarce and very irregular precipitation from year to year, the only feasible crops are winter cereals, which, in many years, remain unprofitable. Earning CAP subsidies compels farmers to expand the plowed surface, even into saline depressions of remarkable environmental value hosting endemic and endangered species. Moreover, land consolidation, pipelines, pumping stations, roads, or other works associated with the new irrigated areas, have increased the degradation or disappearance of habitats (Castañeda and Herrero, 2008; Herrero and Castañeda, 2009) leading to a decrease in the extent of natural vegetation.

Maps are needed to identify soil features that limit agricultural production and to pinpoint pedodiversity spots. The agri-environmental rules can be adapted to better allocate subsidies, without increasing the CAP budget. The new allocation rules ought to encourage farmers to manage their land in a way that saves on labor and farm inputs, as well as address nature conservation issues related to biodiversity (van der Horst, 2007) and pedodiversity.

This paper presents an integrated methodology aimed at identifying low production areas where plowing-exemption rules should be implemented as a means for promoting habitat protection on a local scale. The methodology takes into account rural practices and seeks the agreement of local farmers.

\section{Material and Methods}

As a starting point, information was available from environmental and agricultural Geographical Information System (GIS) sources. The environmental data were the wetland inventory (Castañeda and Herrero, 2008), the 1:5000 scale maps of halophilous vegetation (Domínguez et al., 2006), and the Special Protection Area (SPA) for birds (European Union, 1979). The agricultural data were the Spanish Farming Land Geographic Information System (SIGPAC), and the 2005-2006 alphanumerical data from the GIS of Herbaceous Crops of the Spanish Ministry of Agriculture, Fisheries and Food.

In order to select agri-environmental plots for soil prospecting, a new GIS database was created using the most detailed SIGPAC delimitations as the basic geographic unit, i.e. the plots declared by farmers for CAP subsidies. The above-mentioned environmental and agricultural data were superimposed onto the farming plots' GIS coverage, together with an image of the Quickbird satellite acquired on July 11, 2007.

Using GIS, we first identified the agri-environmental plots adjacent to the saladas (Figure 1) because of their sensitivity to biodiversity conservation. For this purpose we drew a buffer line $200 \mathrm{~m}$ from the edge of the saladas. When a farming plot was only partially included within the 200-m limit, the entire plot was computed. All these farming plots were extracted from the database furnished by the Government of Aragon. Four of the accessible saladas (Agustín, Gramenosa, Guallar and Salineta) were selected as representative of dry-farming, imminent irrigation, and Natura 2000 areas (Figure 1). 
We contacted 26 people from the list of CAP subsidy recipients in the municipality of Bujaraloz (Mendez, 2006). Only 16 agreed to be interviewed. Most of them were land managers, representing a total of 34 subsidy recipients. A poll was carried out in order to learn their opinions and concerns about a new agricultural measure to be applied under the Natura 2000 conservation policy. The local officers in charge of environment and agriculture were also interviewed.

We delimited low production enclaves in the agri-environmental plots selected by means of a visual analysis of the Quickbird image. The 432 RGB composition showed a number of white patches close to the wetlands, and some prominent patches in nearby additional plots. A subsequent field survey was carried out to decide on the prospecting sites using geomorphologic and soil surface color criteria (white, dark, and reddish colors), allowing for sampling points of contrasting color to be selected.

The soil prospecting was based on auger holes in the four sites selected. The most contrasting color patches were found around Agustín. The prospecting there was then intensified by describing the soil surface and opening pits for pedon study. Crop development at several stages was also recorded, as was the yield from three randomly selected $0.25 \mathrm{~m}^{2}$ areas around the pit location.

A total of 117 soil samples were taken for laboratory analysis. The results shown here are for (i) electrical conductivity in saturation extracts (ECe) and 1:5 soil to water ratio extracts (EC1:5), according to US Salinity Laboratory Staff (1954); (ii) calcium carbonate equivalent $(\mathrm{CCE})$ by titration of excess $\mathrm{HCl}$, a method validated by the Laboratory of the Aragón Government as yielding results similar to the Bernad calcimeter; and (iii) gypsum by thermogravimetry (Artieda et al., 2006).

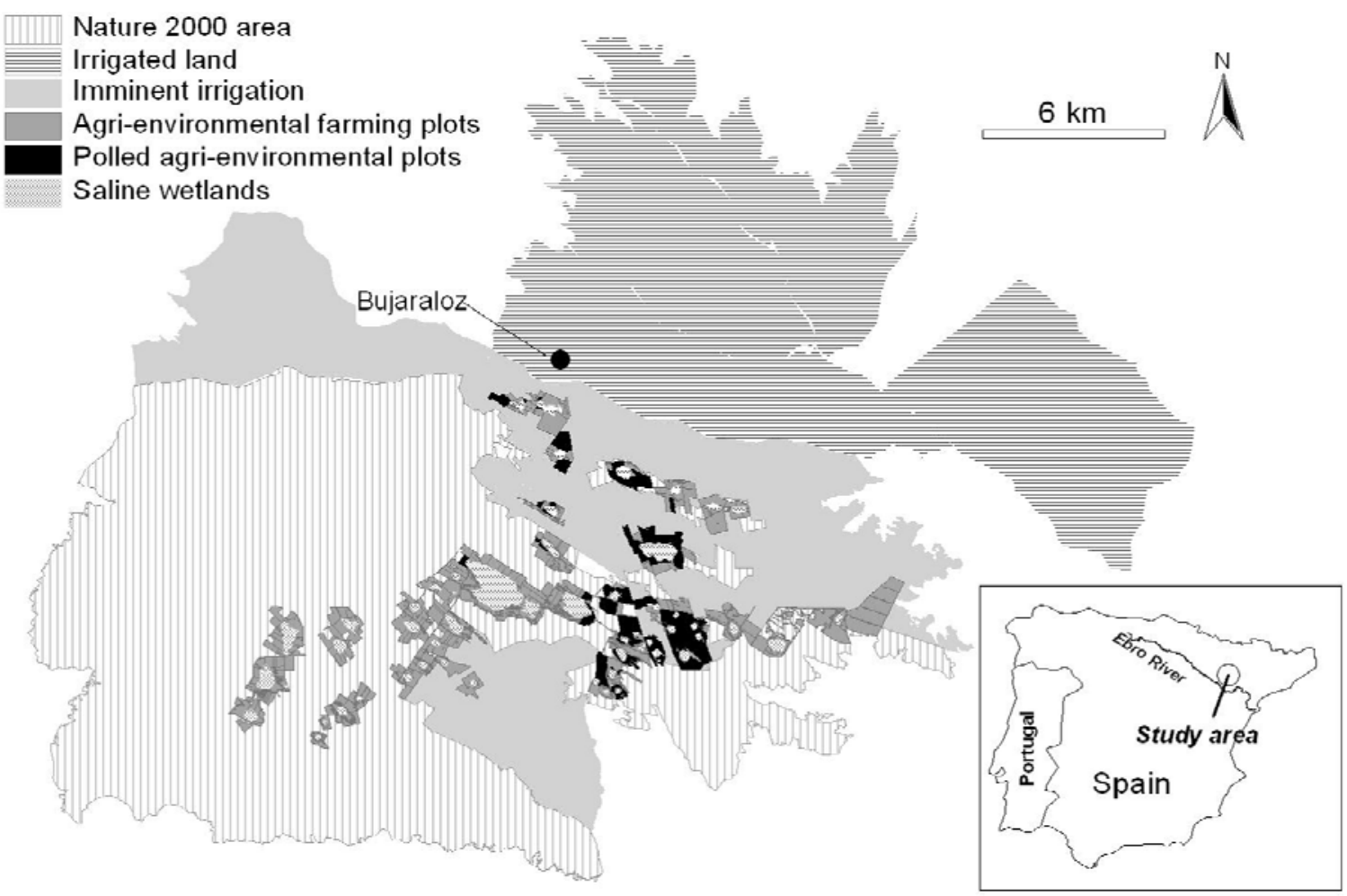

Figure 1. Location of the study area and the selected farming plots. Most of the area not included in Natura 2000 is, or will be, equipped for irrigation with Pyrenean water. 


\section{Results and discussion}

The farming plot database contains 1264 plots located in the wetland environment, with a total surface area of 5747 ha, five times the wetland surface extent. SPA for birds covers $81 \%$ of the surface area of the selected agri-environmental plots, and $19 \%$ is included in the near future irrigation. The poll was carried out over 936 ha, i.e. 111 farming plots, or $16 \%$ of the selected agri-environmental surface area extent. The size distribution of the polled plots was similar to that of the plots of the entire area studied.

The opinions gathered from the interviewees were attributed to the number of hectares they were responsible for. The subsidy recipients were direct cultivators of only $50 \%$ of the polled surface area. Three respondents managed around $80 \%$ of the polled area, indicative of the disappearance of small farming enterprises. Hence, the decisions made by few people will impact large areas. From a total of 27 agriculture/environment ideas discussed in the interviews, we concluded that $37 \%$ of those polled agreed with a new plowing exemption measure, $30 \%$ agreed but strictly in exchange for legal economic compensation, and 16\% were distrustful about future changes of the CAP. Environment officers would prefer a measure adapted to the existing agri-environmental program, while agricultural officers were uncertain about the technical and economical feasibility of its application, although they approved of new agri-environmental measures, especially nonplowing. The poll confirmed the farmers' interest in the production of detailed maps of soil features limiting crop production. Farmers had a personal stake in the soil and crop surveys due to the potential source of supplementary income that could result from any habitat protection efforts.

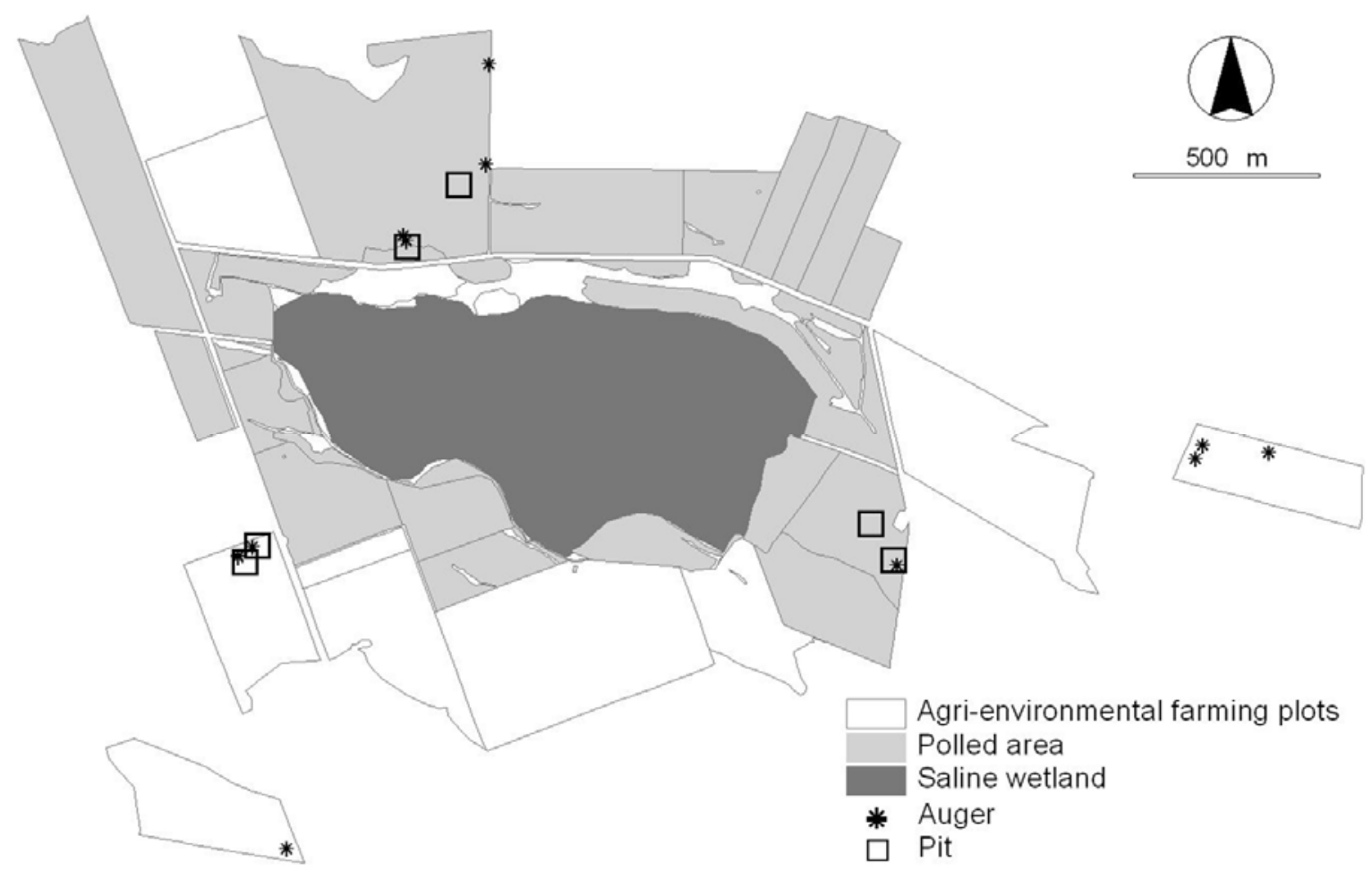

Figure 2. Farming plots in the Agustín site, and points sampled for soil characterization. 
Most of the farming plots studied are located on gentle slopes at the edges of the depressions. Supplemental field inspections showed halophilous vegetation in some patches with stunted barley or durum wheat. The white patches drawn from the Quickbird image occupy $13.4 \%$ of the 711 ha of agri-environmental farming plots, this percentage being different at each site: $20.7 \%$ in Agustín, $10.6 \%$ in Guallar, $8.4 \%$ in Pito, and $10.3 \%$ in Salineta.

The grain production measured in 2008 ranges from $0 \mathrm{~kg} / \mathrm{ha}$ to $639 \mathrm{~kg} / \mathrm{ha}$. These figures translated into agricultural production equivalent to a zero yield, because harvesting becomes unprofitable. Bad agricultural years are frequent in this area, characterized by a mean yield of $900 \mathrm{~kg} \mathrm{ha}^{-1}$ (McAneney and Arrúe, 1993), strongly conditioned by rainfall during cereal growth and by the application of herbicides.

The soil sampling depth ranged from $30 \mathrm{~cm}$ to $150 \mathrm{~cm}$ (Table 1). Most of the white patches are in the top positions with shallow lithic or paralithic contacts, as shown by a more frequent occurrence of the shallow auger holes in these patches.

Table 1 shows the ranges of ECe, gypsum, and CCE for the samples at each site studied. For all samples, ECe ranges from $0.7 \mathrm{dS} \mathrm{m}^{-1}$ to $30.3 \mathrm{dS} \mathrm{m}^{-1}$ with $80 \%$ of the samples having ECe $<8 \mathrm{dS} \mathrm{m}^{-1}$. CCE ranges from $2.7 \%$ to $58.6 \%(\mathrm{w} / \mathrm{w})$, with $66 \%$ of samples having $>20 \% \mathrm{CCE}$, and $18 \%$ having $>40 \% \mathrm{CCE}$.

Gypsum content determinations give results from $0.5 \%$ to $94.7 \%$, with $51 \%$ of samples having $>40 \%$ gypsum and $39 \%$ with $>60 \%$ gypsum. For the six samples giving results $<2 \%$, a qualitative test of gypsum would be needed for confirmation (Artieda et al., 2006). The six samples come from the dark patches. Five of them are neither saline nor saturated in calcium sulfate $\left(\mathrm{EC} 1: 5<1.5 \mathrm{dS} \mathrm{m}^{-1}\right)$; the other one is very saline $(\mathrm{EC} 1: 5=$ $3.66 \mathrm{dS} \mathrm{m}^{-1}$, and $\mathrm{ECe}=10.43 \mathrm{dS} \mathrm{m}^{-1}$ ). The gypsum content in these six samples is assumed to be insignificant. All soil samples from the Salineta site have higher CCE than gypsum.

Table 1. Soil sampling sites, sampling techniques used, and ranges of: depth, ECe, calcium carbonate equivalent (CCE), and gypsum content.

\begin{tabular}{|c|c|c|c|c|c|c|}
\hline \multirow{2}{*}{$\begin{array}{l}\text { Sampling } \\
\text { site }\end{array}$} & \multirow{2}{*}{$\begin{array}{l}\text { Number of pits (P) } \\
\text { and auger holes (A) }\end{array}$} & \multirow{2}{*}{$\begin{array}{l}\text { Number of } \\
\text { soil samples }\end{array}$} & Depth & ECe & CCE & Gypsum \\
\hline & & & $\mathbf{c m}$ & dS $m^{-1}$ & $\% \mathrm{w} / \mathrm{w}$ & $\% \mathrm{w} / \mathrm{w}$ \\
\hline \multirow{2}{*}{ Agustín } & $6 \mathrm{P}$ & 20 & $80-150$ & $3.0-13.4$ & $2.7-46.7$ & $1.6-94.7$ \\
\hline & $12 \mathrm{~A}$ & 47 & $50-125$ & $2.0-20.3$ & $6.9-41.4$ & *in. -89.3 \\
\hline Guallar & $7 \mathrm{~A}$ & 20 & $30-110$ & $3.3-19.5$ & $7.1-49.8$ & 9.9-94.6 \\
\hline Pito & $5 \mathrm{~A}$ & 14 & $25-100$ & $0.9-30.3$ & $5.1-41.9$ & $1.9-90.4$ \\
\hline Salineta & $5 \mathrm{~A}$ & 16 & $50-125$ & $0.7-15.4$ & $22.6-58.6$ & $1.9-19.5$ \\
\hline
\end{tabular}

* in. = insignificant.

As expected, the color of the soil surface detected by means of remote sensing is related to the gypsum and CCE content in the upper horizon. Figure 3 shows the difference between white and dark patches. The sum of gypsum and CCE at the upper horizon is about $100 \%$ in most white patches, indicative of the general lack of clay minerals or other non-soluble components in the soil, especially at the depth of roots. Dark patches, 
frequently in gentle hollows where the organic matter, clay, and moisture accumulate, have $<50 \%$ gypsum plus CCE, allowing for better growth of the cereal in dry years.
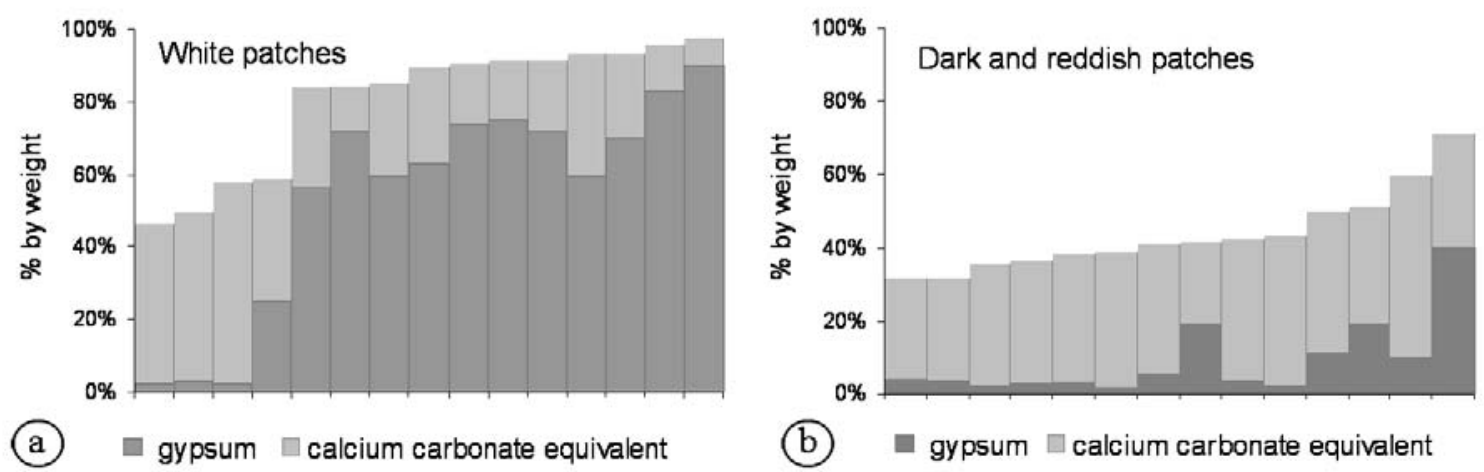

Figure 3. Gypsum and calcium carbonate equivalent in auger soil samples of the upper horizons $(0-25 \mathrm{~cm})$ in the white (a) and the dark and reddish (b) patches.

Provided that gypsum is ubiquitous in the landscape, soil samples with ECe $\leq 2.25$ $\mathrm{dS} \mathrm{m}{ }^{-1}$ cannot be deemed saline. Aridity is the key constraint for life in Monegros. Main plant stresses are related to (1) lithic or paralithic contacts at shallow depths, (2) occurrence of horizons with low clay content near the surface, due to high gypsum and/or calcium carbonate contents, and (3) saline horizons, i.e. occurrence of salts more soluble than gypsum somewhere in the soil profile. These soil features were considered the blueprint for easy criteria to identify low crop production areas. Their future mapping and the analysis of their distribution in the soil profile will provide basic knowledge on favoring pedodiversity and biodiversity.

\section{Conclusions}

The considerable amount of information from different database sources, processed by means of GIS tools, enabled the recognition of farming plots with agri-environmental interest and the selection of the farmers for the opinion poll.

The low production criteria extracted from the analyses of satellite images and from the soil survey (presented here in a test area) are complementary, and the results are coincident. The soil prospection reveals soil salinity and the high gypsum and calcium carbonate content as significant pedodiversity criteria. These soil features condition production in the dry-farmed area, and their mapping can help to reconcile agriculture with habitat conservation. We consider it worthwhile to extend these criteria to the remaining farming plots.

The GIS database created and the consultative approach will be advantageous for the systematic selection of plots for agri-environmental purposes. A measure for plowing exemption - without a decrease in CAP subsidies to farmers- in low-production areas with environmental value would combat the degradation of biodiversity and soils. Farmers would be rewarded by saving on agricultural inputs, with no increase in the CAP budget. 
Acknowledgements. This article is a result of projects AGL2006-01283 and GALC0062008.

\section{References}

Artieda O, Herrero J, Drohan PJ 2006 A refinement of the differential water loss method for gypsum determination in soils. Soil Sci Soc Am J 70: 1932-1935.

Baltanás A 2001 Candelacypris n. gen. (Crustacea, Ostracoda): a new genus from Iberian saline lakes, with a redescription of Eucypris aragonica Brehm \& Margalef, 1948. Bulletin de la Société des Naturalistes Luxembourgeois 101: 183-192.

Braun-Blanquet B, Bolòs O 1958 Les groupements végétaux du bassin moyen de l'Ebre et leur dynamisme. Anales de la Estación Experimental de Aula Dei 5: 1-266.

Casamayor E, Castañeda C, Pena A, Vich MA, Herrero J 2005 Monegros: riqueza escondida bajo la sal del desierto. Investigación y Ciencia 349: 38-39.

Castañeda C, Herrero J 2008 Assessing the degradation of saline wetlands in an arid agricultural region in Spain. CATENA 72: 205-213.

Domínguez M, Conesa JA, Pedrol J, Castañeda C 2006 Una base de datos georreferenciados de la vegetación asociada a las saladas de Monegros. In: Camacho MT, Cañete JA, Lara JJ (eds) El acceso a la información espacial y las nuevas tecnologías geográficas. Actas del XII Congreso Nacional de Tecnologías de la Información Geográfica. University of Granada, Spain, September 2006.

European Union 1979. Council Directive 79/409/EEC of 2 April 1979 on the conservation of wild birds. Official Journal of the European Communities, Luxembourg, 103: 1-18.

Herrero J, Castañeda C 2009 Delineation and functional status monitoring in small saline wetlands of NE Spain. J Environ Manage, doi: 10.1016/j.envman.2007.06.026.

McAneney KJ, Arrúe JL 1993 A wheat fallow rotation in northeastern Spain: water balance-yield considerations. Agronomie 13: 481-490.

Melic A, Blasco-Zumeta J (eds) 1999 Manifiesto Científico por los Monegros. Boletín de la Sociedad Entomológica Aragonesa 24: 1-266.

Mendez S 2006 Intégration d'indices agro-environnementaux auprès des acteurs locaux de las saladas du sud de Monegros. Project of Master Professionnel d'Ingénierie en Écologie et en Gestion de la Biodiversité. Université des Sciences et Techniques de Montpellier. Francia.

Pedrocchi C 1998 Ecología de los Monegros. Instituto Estudios Altoaragoneses, Huesca.

US Salinity Laboratory Staff 1954 Diagnosis and improvement of saline and alkali soils. Agric. Handbook, vol 60. US Gov Print Office, Washington, DC.

Van der Horst D 2007 Assessing the efficiency gains of improved spatial targeting of policy interventions; the example of an agri-environmental scheme. J Environ Manage 85: 1076-1087. 